\title{
Late Carboniferous Macroflora from Rod El-Hamal Formation Wadi Araba, North Eastern Desert, Egypt
}

\author{
Mona H. Darwish ${ }^{*}$ and Yasser A. El Safori ${ }^{2}$
}

${ }^{1}$ Department of Botany, College of Women for Science, Arts and Education, University of Ain Shams, Egypt.

${ }^{2}$ Geology Department, Faculty of Science, Ain Shams University, 11566 Cairo, Egypt.

*Corresponding author: monahd2000@yahoo.com

\begin{abstract}
The Late Carboniferous of Rod El-Hamal Formation, Wadi Araba has some fossil plant remains content. The systematic description of these remains reveals the identification of twelve species representing Lycophyta, Sphenophyta, Pteridospermatophyta, and Cordaitophyta. All are recorded for the first time from this formation.
\end{abstract}

\section{Key words}

Cordaitophyta, Late Carboniferous, Lycophyta, Pteridospermatophyta, Sphenophyta, Rod El-Hamal Formation,Wadi Araba

\section{Introduction}

Fossil plants were described from Egypt from ages starting from Devono-Carboniferous (345 mys) (LejalNicol 1987) to Quaternary (2.5 mys) (Darwish and Awad 2002). Regarding the Carboniferous flora of the country, it has been studied by numerous workers. Up till now, 133 fossil plant taxa have been reported from this age (16 from Devono- Carboniferous, 91 from Early Carboniferous,9 from Carboniferous and 17 from Late Carboniferous) [ cf. Salter 1868; Newton 1909; Ball 1916; Cuvillier 1928; Seward1932; Jongmans and Koopmans 1940; Jongmans and Van Der Heide 1955; Boureau 1954 \& 1958; Horowitz 1973; Lejal-Nicol1987 \&1990; Issawi \& Jux 1982; Barakat et al.1984; Klitzsch and Lejal-Nicol 1984; Darwish,1990; Yousef 1993; Darwish and ElKelani 2001]. The majority (126 species) of the reported fossils belong to pteridophytes while a small minority ( 7 species) belongs to gymnosperms.

The Late Carboniferous fossil plants of Egypt (16 taxa) were reported from many places, namely Wadi Um Shebba (Ball 1916), Wadi Araba (Kräusel and Stromer1924, Kräusel 1939; Lejal-Nicol 1987), West Central Sinai (Barakat et al. 1984), Wadi Malik (LejalNicol 1987), Gulf of Suez near Bir Qeseib, north Galala, Gebel Uweinat(Lejal-Nicol 1990)(See Fig. 1; Table 1).

Fossil plants reported from Wadi Araba come from different geologic ages: one from Lower Carboniferous (Boureau 1958), one from Carboniferous (Cuvillier 1928),10 from Lower Permian (Lejal- Nicol 1987), one from Permian (Schürmann et al. 1963 and Lejal- Nicol 1990), one from Jurassic (Seward, 1907) and 5 from
Cretaceous (Kräusel and Stromer 1924 and Kräusel 1939). Those 19 fossil plant taxa recorded from Wadi Araba include: 3 Sphenophyta; 4 Pterophyta; 4 Pteridospermatophyta; 3 Cordaitophyta; 2 Coniferophyta; one Gymnosperm (not referred to a family) and one Angiosperm. The aim of this paper is to describe and illustrate fossil plants from Rod El-Hamal Formation for the first time to further our knowledge about the Late Carboniferous plants of Wadi Araba, western side of the Gulf of Suez, Egypt. For this reason, fossil specimens were collected from Rod El-Hamal Formation (Fig. 2).

\section{Geology of the study area}

The Carboniferous rocks of Egypt are deposited in a far East inland sub-basins of the Sahara region of north Africa that forms the northern margin of Gondwana during the Late Mississippian/Early Pennsylvania (Cózaret al. 2015) Shallow siliciclastic/carbonate mixed platform developed on the continent margin as recorded from Morocco, Algeria and Libya. Minor records with sporadic occurrences are recorded from Egypt as exposed on western side of the Gulf of Suez, Eastern Desert and south Western Desert. The outcrops are studied from westcentral Sinai at Urn Bogma, Wadi Feiran and Abu Durba, Northern Galala, Abu Darag, Wadi Araba and in Wadi EIDakhal, Wadi Malik and Gebel Uweinat. Beside the stratigraphic position most of the studied rock units are dated and correlated according to some fossiliferous horizons as late Carboniferous; Said (1962); Abdallah and El-Adindani (1965); Omara and Kenawy (1966); Klitzsch (1990); Kora and Mansour (1992); Kora (1995); AbdelShafy et al. (2000); El-Shazly (2011) and El Safori (2015). 

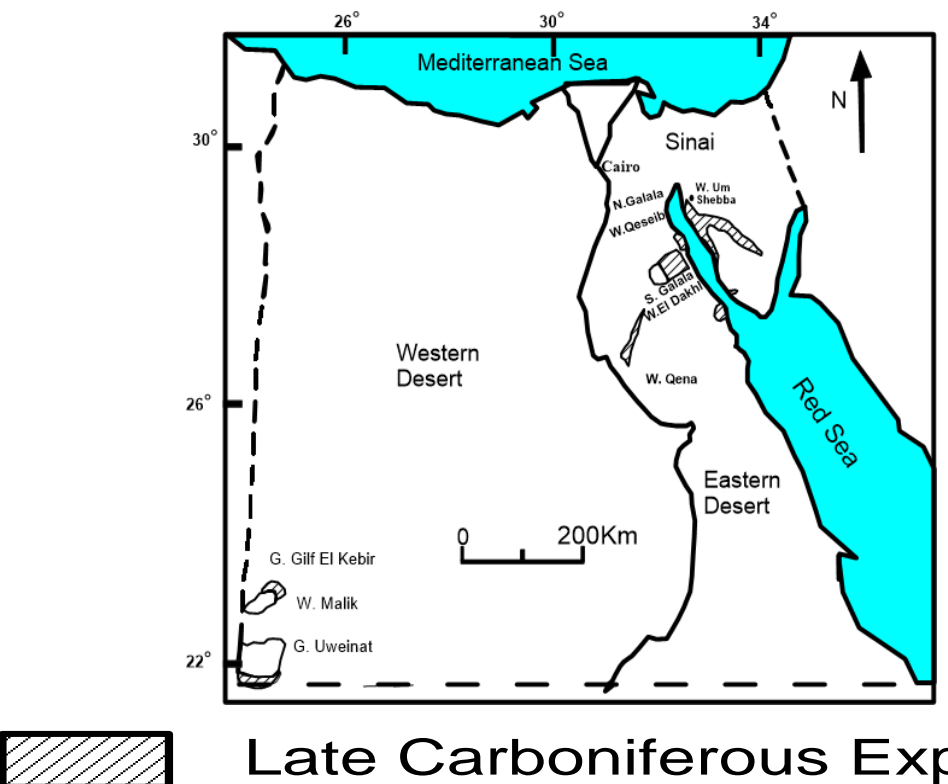

\section{Late Carboniferous Exposures}

Fig.1. General distribution map of the Late Carboniferous rocks of Egypt (after Abdallah and El-Adindani 1965).

Table 1. The 15 Late Carboniferous fossils recorded up till now from Egypt (based on: 1. Ball 1916; 2. Kräusel and Stromer 1924; 3. Kräusel 1939; 4. Barakat et al. 1984; 5. Lejal-Nicol 1987; 6. Lejal-Nicol 1990), Ref. = references.

\begin{tabular}{|c|c|c|c|}
\hline Division & Taxa & Localities & Ref. \\
\hline \multirow[t]{3}{*}{ Lycophyta } & Lepidodendron posthumi Jongmans \& Gothan & $\begin{array}{l}\text { Gulf of Suez near Bir } \\
\text { Quseib, north Galala }\end{array}$ & 6 \\
\hline & Lepidodendron sp. & $\begin{array}{l}\text { West Central Sinai from } \\
\text { Wadi Um Shebba }\end{array}$ & 1 \\
\hline & Sigillaria icthyolepis Persl in Sternberg sensu Weiss & Gulf of Suez near Bir & \\
\hline & Syringodendron sp. & Quseib, north Galala & 6 \\
\hline & Sigillaria sp. & West Central Sinai & 4 \\
\hline & Cf. Tunguskadadendron sp. & \multirow{3}{*}{$\begin{array}{l}\text { Gulf of Suez near Bir } \\
\text { Qaseib, northern Galala }\end{array}$} & \multirow{3}{*}{6} \\
\hline \multirow[t]{2}{*}{ Sphenophyta } & Equisetites sp. & & \\
\hline & Eremopteris (Sphenopteris) aff. souichii Zeiller & & \\
\hline \multirow[t]{2}{*}{ Pterophyta } & Rhodealontzenensis Stockmans \& Williere & \multirow{4}{*}{ G. Uweinat } & \multirow{4}{*}{6} \\
\hline & Rhodea sp. & & \\
\hline \multirow[t]{3}{*}{ Cordaitophyta } & Cordaites angulostriatus Grand’Eury & & \\
\hline & Cf. Artisia sp.? & & \\
\hline & Cf. Cordaites regularis Ledran & W. Malik & 5 \\
\hline \multirow[t]{2}{*}{ Coniferophyta } & Lebachia hypnoides Florin & \multirow{2}{*}{$\begin{array}{l}\text { Gulf of Suez near Bir } \\
\text { Quseib, north Galala }\end{array}$} & \multirow[t]{2}{*}{6} \\
\hline & Walchia sp. & & \\
\hline
\end{tabular}




\section{Late Carboniferous Macroflora from Rod El-Hamal Formation Wadi Araba}

Table 2. Plant Fossils recorded, up till now, from Wadi Araba (different geological ages from Lower Carboniferous to Cretaceous. Based on: 1. Boureau 1958; 2. Cuvillier 1928; 3. Lejal- Nicol 1987; 4. Schürmann et al. 1963; 5. LejalNicol 1990; 6. Seward 1907; 7. Kräusel and Stromer 1924; 8. Kräusel 1939. Ref. = references.

\begin{tabular}{|c|c|c|c|c|c|}
\hline Taxa & $\begin{array}{l}\text { Carbonifero } \\
\text { us }\end{array}$ & & $\begin{array}{c}\text { Lower } \\
\text { Jurassic }\end{array}$ & Cretaceous & Ref. \\
\hline & $\mathrm{C}$ & $\mathrm{L}$ & & & \\
\hline Sphenophyta & & & & & \\
\hline Lobatoannularia aff. Lingulata Halle & & + & & & \\
\hline Cf. Lobatoannularia sp. & & + & & & 3 \\
\hline Sphenophyllum thonii var. minor $\underline{\text { Sterzel }}$ & & + & & & \\
\hline Pterophyta & & & & & \\
\hline Astherotheca aff. Leeukuilensis Anderson \&And & & + & & & 3 \\
\hline Cladophlebis sp. & & & + & & 6 \\
\hline Paradoxopteris stromeri Hirmer & & & & + & 8 \\
\hline Weichselia reticulate S.W.F.A. & & & & + & \\
\hline & permatophyt & & & & \\
\hline Autunianconferta (Sternb.) Kerpv .vulgaris Weis & & + & & & 3 \\
\hline Gangamopteris sp. & & + & & & \\
\hline Thinnfeldia aff. Decurrens (Brann) Schenk & & + & & & \\
\hline Eremopteris (Sphenopteris) aff. Souichii Zeiller & + & & & & 1 \\
\hline & daitophyta & & & & \\
\hline Cordiatenthus aff. Duquesnensis Rothwell & & + & & & 3 \\
\hline Cordaites sp. & & & & & $4 \& 5$ \\
\hline Dorycordaites sp. Ziller & & + & & & 3 \\
\hline & iferophyta & & & & \\
\hline Araucarioxylon & + & & & & 2 \\
\hline Lebachia aff.hypnoides(Brongniart) Florin & & + & & & 3 \\
\hline Gymnospe & t referred to & $\mathbf{F a}$ & & & \\
\hline Dadoxylon aegyptiacum Unger & & & & + & $7 \& 8$ \\
\hline ?Ebemoxylon & & & & + & 8 \\
\hline & giosperms & & & & \\
\hline Nelumbites schweinfurthi Fritel & & & & + & 8 \\
\hline
\end{tabular}




\section{Mona H. Darwish and Yasser A. El Safori}

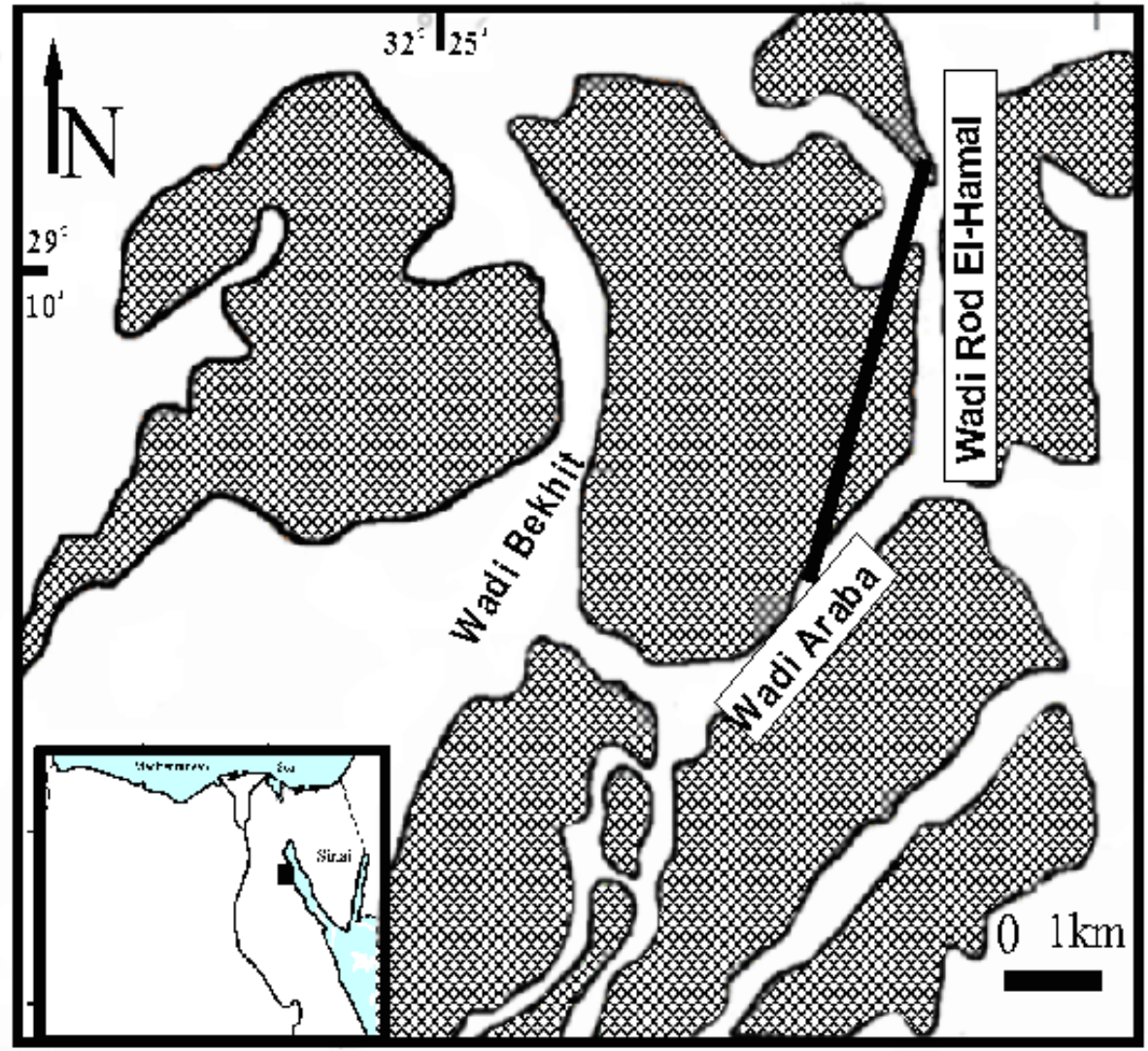

Fig.2. Location map of the study area showing the outcrops of Rod El-Hamal Formation and the traverse of the studies composite section.

The study area covers a part of Wadi Araba on the western side of the Gulf of Suez at the intersection between the two wadies of Araba and Rod El- Hamal. The basal contact is unexposed while its upper contact is overlain by Cretaceous and Paleogene successions. Only one composite section was measured along the study area from west to east where units get younger.

\section{Stratigraphy}

The stratigraphic section measures $212 \mathrm{~m}$ and is composed of five major rock units, exhibiting different lithologic criteria and fossil contents. Also, the depositional environments exhibiting gradual faces progress from delta to proper marine deposits. They can be described as follows from base to top:

I- Shale unit: This unit measures $47 \mathrm{~m}$ and composed of olive green/greyish green/dark greyish green shale. The upper part is intercalated with argillaceous sandstone with imprints permineralized, molds, casts and permineralized wood. The deposits are laid down under deltaic front environments sometimes interrupted by coarser sedimentation resulted from fluvial influx increments during intermittent warm environments which also accompanied by plant fragments (Fig. 3) (Plate 4, Fig. 1, 3 \& 4).

2- Claystone/Sandstone unit: This unit measures 43m and composed of light brownish yellow fluvial claystone with sandstone interbeds and plant remains, crinoids and bryozoa at the lower part (Fig. 3).

3- Sandstone unit: This unit measures $40 \mathrm{~m}$ and composed light of brownish yellow medium grained sandstones. They are laid down mostly under estuary environments. 4- Carbonates/Sandstones unit: This unit measures $37 \mathrm{~m}$ and composed of reddish shallow marine argillaceous dolomitic limestones with claystone and sandstone intercalations. The unit ended with highly fractured, cross stratified sandstone that followed by highly fossiliferous marine limestone. This horizon is rich in different proper marine fauna of crinoids, corals, bryozoans and brachiopods.

5- Carbonate/Claystone unit: This unit measures $45 \mathrm{~m}$ and composed of light greenish grey calcareous claystone with fossiliferous limestone with bivalves' fossil banks. The unit is ended by fragmentary limestone bed. 


\section{Late Carboniferous Macroflora from Rod El-Hamal Formation Wadi Araba}

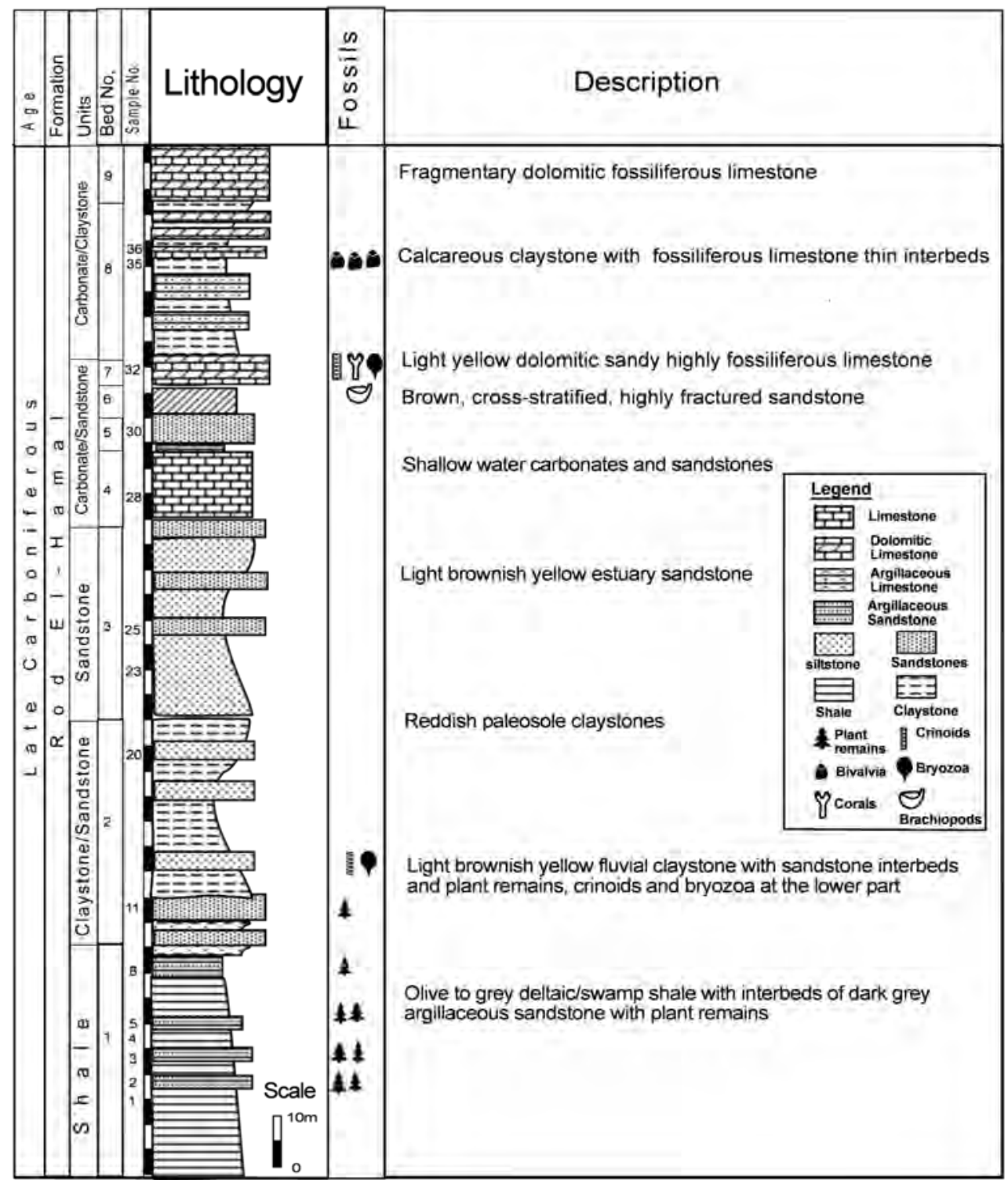

Fig. 3. Lithostratigraphic succession of Rod El-Hamal Formation at Wadi Araba area.

\section{Material \& Methods}

Twenty-one fossiliferous slabs were collected by Prof. Dr. Marouf A. Abd Elhameed (Geology Department, Faculty of Science Ain Shams University) from the shale Unit of the Late Carboniferous Rod El-Hamal Formation of Wadi Araba on the western side of the Gulf of Suez (Fig. 2\&3). Slabs are rich with plant remains and are in the form of imprints permineralized, molds, casts and permineralized wood. The fossils vary in color between light brownish to yellow. The matrix and plant remains have the same color; all remains have been photographed. The slabs are numbered from 1-12 and kept in the palaeobotanical collection of the Botany Department, Women College Art, Science and Education, Ain Shams University.

\section{Results}

Plant remains are in a fragmentary condition, so that it is difficult to give full descriptions or precise identifications. The fossil plants represent twelve forms, all of them are new to Rod El-Hamal Formation. Leaves, stems and roots belonging to Lycophyta; Sphenophyta; Pteridospermatophyta, Cordaitophyta and small pieces of petrified woods (postponed to further study hoping find letter specimens) represent the twelve forms. Determination was, therefore, based on surface features of stems, roots, shape and venation of leaves which though insufficient, yet they represent the only information available 


\section{Late Carboniferous Macroflora from Rod El-Hamal Formation Wadi Araba}

\section{Systematic Order}

\begin{tabular}{|l|l|}
\hline Kingdom & Plantae Haeckel 1866 \\
\hline Division & Lycopsida \\
\hline Order & Lepidodendrales \\
\hline Family & Lepidodendraceae \\
\hline Genus & Lepidodendron Sternberg 1820 \\
& L. veltheimi Sternberg 1825 \\
\hline & L. rimosum Sternberg 1820 \\
\hline Genus & L. lycopodioides Sternberg 1823 \\
\hline Division & Bothrodendron Lindley et Hutton 1833 \\
\hline Order & Bothrodendron cf. punctatum 1833 \\
\hline Family & Sphenopsida \\
\hline Genus & Equisetales \\
\hline Subgenus & Calamitaceae \\
\hline Calamites Suckow 1784 \\
\hline Division & C. (Crucicalamites) cruciatus Sternberg 1825 \\
\hline Order & Mesocalamites Hirmer, 1927 \\
\hline Family & C.( Mesocalamites ) roemeri Goeppert Hartung 1938 \\
\hline Genus & Gymnospermopsida \\
\hline Genus & Medullosales Corsin, 1960 \\
\hline Division & Alethopteridaceae Corsin, 1960, emend. Anderson et al. 2007 \\
\hline Family & Callipteridum Weiss 1870 \\
\hline & Callipteridum sp. \\
\hline & Cordaitopsida \\
\hline & Cordaitales \\
\hline & Cordaitaceae \\
\hline Cordaites Unger 1850 \\
\hline Cordaites sp \\
\hline Artisia Sternberg 1838 \\
\hline Artisiaapproximate Brongniartex Lindley\&Hutton 1837 \\
\hline ?Artisiatransversa(Artis) Corda in Sternberg 1838 \\
\hline & Unidentified roots \\
\hline Woody trunks \\
\hline
\end{tabular}

\section{Lepidodendrales}

Isolated vegetative shoots of lycophytes are notoriously difficult to identify when preserved as compressionimpression specimens (Thomas and Meyen 1984). The characters which are of value for generic delimitation are after Meyen (1976) as follows: Leaf cushion (LC) and Leaf scar (LS). Under this term authors have included either the lowermost part of the leaf which is usually widened and remaining on the stem after leaf abscission, or a swelling of the axis itself associated with a leaf, visible even in decorticated states of the latter (Grierson and Banks 1963). We adopt the first sense of the term, like the majority of palaeobotanists. Leaf scar (LS) is a part of LC corresponding to the abscission layer. 


\section{Mona H. Darwish and Yasser A. El Safori}

\section{Genus Lepidodendron Sternberg, 1820}

This genus accommodates stem impressions with leaf cushions of bark in spiral arrangement, rhomboidal to narrowly rhomboidal, acute at both ends. Central leaf scars are rhomboidal and perpendicular to the long axis of the leaf cushion. The leaf cushions bear a medial line separating two parichnos scars (Dilcheret al.2005).

Specimen No. 4. Lepidodendron veltheimii Sternberg 1820 (Plate 1, fig. 1) \& (Plate 4, fig. 3).

Description: The specimen is a portion of a stem. Length isapproximately $20 \mathrm{~cm}$ and $10 \mathrm{cmin}$ width. Leaf cushions (LC, sensu Thomas and Meyen 1984) are bulge slightly, and are small, 25-30 $\mathrm{mm}$ long, 3-4 $\mathrm{mm}$ wide. LC dimensions (i.e. length, width and inter areas) show considerable variation, so the shapes of LC range from fusiform, to longitudinally rhomboid. The upper and lower tip end of LC are little or inflected in opposite directions, generally contiguous but separated from each other by a little distance (about $1 \mathrm{~mm}$ wide). In all cases, the details of LS are not well revealed by the sandy matrix.

Comparisons: Specimen No.4 is somewhat similar to $L$. VeltheimiiSternberg which was described from Lower Carboniferous of Wadi El-Dakhaland Abu Thora (by Lejal-Nicol 1987; Darwish and El-Kelani 2001. respectively) with differences in dimensions.

Specimen No. 2. Lepidodendron rimosum, Sternberg 1820 (Plate 1, fig. 3).

Description: The specimen is a portion of a stem. LC length is $40-45 \mathrm{~mm}$ and 5-7 mm width, rhomboidal, elongated and acuminate at both ends, convex, carinate, with rounded lateral angles and sharp bases and apices, slightly inflected in opposite directions, closely resemble those of Sternberg's type (seelvarez- V.zquez and Wagner 2014). The prominent, relatively small, rhomboidal LS, placed a little above the middle of a cushion are also similar. Different wide separation between leaf cushions. Němejc (1947, p. 62) consider that the wide separation between leaf cushions in the holotype merely represented a developmental stage in the lower part of an old tree and that this character was useless for specific distinction (see, lvarez-V. zquez and Wagner 2014). The leaf-trace scar and parichnos scars are badly preserved.

Comparisons: Specimen No. 2 is somewhat similar to "Lepidodendron" rimosum Sternberg 1820 which was described by lvarez-V. zquez and Wagner (2014) from lower to middle Westphalian of the Maritime Provinces of Canada but there are some difference of dimensions and similar to L. fusiforme (Corda) Unger from the Dobrudzha coalfield, Bulgaria of Pennsylvanian (Upper Carboniferous) (Tenchov and Thomas 2015) but differ in wide interareas and dimensions. Also, the lateral angles of the cushions are more acute or only very slightly rounded in L. fusiforme.

Specimen No. 6. Lepidodendron lycopodioides Sternberg 1823 (Plate 1, fig. 2).
Description: The specimen is a portion of a stem. LC bulge slightly, 34-37mm long and 3-3.5 mm width. LC dimensions (i.e. length, width and interareas) show considerable variation, so the shapes of LC range from fusiform, to longitudinally rhomboid, to obliquely oval, narrowed and acuminate at both ends, separated by wrinkled areas, narrow parallel ribs and intervals irregularly striate lengthwise. Similar prominent, relatively small, rhomboidal LS, placed a little above the middle of a cushion, slightly broader in the middle, LS and parichnos scars are badly preserved.

Comparisons: The specimen of L. lycopodioides (No. 6) is similar to that found from Carboniferous of United Statesbby Leo Lesquereux (1879) and that from Carboniferous of Poland (http://www.redbor.pl/skamienialosci/0_atlas_flory_karb onu.htm).

\section{Genus Bothrodendron Lindley et Hutton 1833}

The name Bothrodendron was instituted by Lindley and Hutton (1833) for impressions of stems from the English Coal-Measures. It is characterised by having minute dots were recognized as leaf-scars and the cup-like cavities were described as probably connected with the occurrence of large cones. The species are distinguished on the bases of leaf scar shape and ornamentation on their stem surfaces. The stem surface is covered with fine, sinuous, vertical striations (Seward 1910).

Specimen No. 13. Bothrodendron cf. punctatum Lindley and Hutton 1833 (Plate 3, fig. 6).

Description: Specimen No. 12 is portion of a stem. Although the illustration of the specimen is too poor to show the details of the stem surface, it is characterized by a considerable number of minute dots, arranged in aquincuncial manner and a cavity.

Comparisons: Specimen No. 12 is similar to Bothrodendron punctatum Lindley and Hutton 1933 from the English Coal-Measures (see, Seward 1910) and differs from B. minutifolium, var. rotundata Weiss. in the presence of sinuous transverse grooves and narrow ridges bearing numerous small pits (see, Seward 1910).

\section{Order Equisetales}

Historically, the Equisetales included a small number of taxa that were thought to be related to one another on thebasis of their presumed herbaceous habit and lack of secondarytissues. The Equisetales are characterised by the presence of distinct nodes, internodes, and longitudinal internodal ridges on their stems.

The Calamitaceae are arborescent plants with considerable secondary growth. They first appeared in the Late Devonian and reached their peak diversity in the Pennsylvanian, when some forms attained heights ranging from $15 \mathrm{~m}$ to more than $20 \mathrm{~m}$ and were major constituents of the lowland equatorial swamp forest ecosystems. Although calamitacean diversity drastically declined 


\section{Late Carboniferous Macroflora from Rod El-Hamal Formation Wadi Araba}

during the Permian, a few forms persisted locally to the Late Permian (see, Taylor 2009).

\section{Genus Calamites Suckow 1784}

This genus accommodates pith cast with internodes of longitudinal ribs and furrows. The internodes are wider than long and the longitudinal ribs are straight to undulate. The nodal areas possess or lack leaf/branch scars (Dilcher et al. 2005).

Specimen No. 8. Calamites (Crucicalamites cruciatus Sternberg 1825 (Plate 2, fig. 1).

Description: This specimen is represented by a cast of Calamites an ancient relative of modern horsetails. It is a small part of 4 nodes. The internodes are wider than high. The internodes are 24 - $32 \mathrm{~mm}$ length and 54 - $66 \mathrm{~mm}$ wide. Articulations well marked by nodal swellings. Ridges well defined, 2.4 - $3.6 \mathrm{~mm}$ wide, equal, and probably extend the full length of the internodes, converging on each side of the nodal line, not alternating and somewhat inflated at the articulations. Furrows generally 1.2-2.4 wide. Branch scars at least 3 to the node, 4.8-7.2 $\mathrm{mm}$ in diameter, showing central insertion point, clearly marked nodal line.

Comparisons: Specimen No. 8 is similar to Calamites (Crucicalamites) cruciatus Sternberg 1825 from Pennsylvanian flora from Val Sanagra in the Western part of the Southern Alps (Italy) described by Pšeničkaetal. (2012). It is similar to Calamites cruciatusharrisoni Grier collected at Reel's Stone Quarry, East Bellevue, Pa., from the sandstone above the Elk Lick Coal (Grier, 1917) but differ in their dimensions and number of branch scars.

\section{SubgenusMesocalamitesHirmer,1927}

Stems of Mesocalamites Hirmer are believed to represent a morphological intermediate between archaeocalamitean and true calamitean stems because the internode bundles may be alternate or opposite at the nodes (Hirmer 1927) (see, Hübers et al. 2012)

Specimen No. 3. Calamite (Mesocalamites) roemeri Goeppert, 1850 (Plate 2, fig. 2) \& (Plate 4, fig. 4)

Description: Specimen No.3 is a fragment of a stem about10 $\mathrm{cm}$ long, the widest part of the specimen measures 6 $.6 \mathrm{~cm}$, but it is not clear whether this represents the entire width of the specimen or not. Internodes are from $40-50$ $\mathrm{mm}$ wide and from $40 \mathrm{~mm}$ to more long. Ribs are about $2-$ $4 \mathrm{~mm}$ wide. The ribs are either straight or flexuous, mostly straight and either alternating or passing straight through the node forming sharp angles or rounded at nodes; furrows straight, broad.

Comparisons: Specimen No. 3 of Calamites (Mesocalamites) roemeri can be compared with a number of species; it is very similar to Calamites (Mesocalamites) roemeri recorded from Late Carboniferous of Castle Hill Ljubljana (Slovenia) by Kolar - Jurkovšek and Jurkovšek (2007 \& 2012) and that described from Pennsylvanian age of Manning Canyon Shale of Pennsylvanian age by
Tidwell et al. (1988). The specimen differs from $M$. cf. ramifer of La Vilella Baixa of Mississippian flora from theCatalan Coastal Chain and NE Spain (Villalba-Breva, S. \& Martín-Closas, C. 2009) because the latter has a zigzag nodal line and narrower ribs than specimen No. 3.

\section{Order Medullosales}

The Medullosales is an order of pteridospermous seed plants, stems and rachides with a dissected stele and frondlike leaves (Anderson et al. 2007).

\section{Genus Callipteridium Weiss, 1870}

Fronds large, polypinnate; pinnules attached to the rachis by the whole base, often decurrent and the lower descending to the main rachis, connate or disjointed at the base; primary nerve strong, dissolved below the apex; lateral veins oblique, curved in passing to the borders, dichotomous, the basilar attached to the rachis (Leo Lesquereux 1879).

Specimen No. 1. Callipteridium sp. (Plate 2, fig. 3 \& 4).

Description: Specimen No.1 is a part of pinna. Pinna size unknown, rachis sturdy, 1 to $2 \mathrm{~mm}$ wide. Pinnules slightly constricted just above the base; pinnule bases appear to lack the narrow confluence between pinnules. Length of pinnules is from 2- $3 \mathrm{~cm}$ and width is from $1-1.2 \mathrm{~cm}$; pinnules parallel-sided to very slightly convex, with rounded apices. Midrib light marked, straight, extending to near the pinnule apex; lateral veins perpendicular to both the midrib and the pinnule margin, usually once to twice forked near margin and relatively crowded.

Comparisons: Specimen No.1 resembles Callipteridium (Praecallipteridium) virginianum (Fontaine \& White) and C. costeifrom the lower Dunkard in the Appalachians of the first North America Wagner \& Álvarez-Vázquez (2010), the first in perpendicular insertion of pinnules; pecopteroid, parallel-sided pinnules, with rounded apices and the bilateral symmetry characteristic of Callipteridium but a wider variation in pinnule length, differences in arrangement of nerves have been recorded. The second resembles it in lateral veins which seem to be once to twice forked in C. costei, but a wider variation in pinnule width has been recorded. The differences between taxa are slight, but Specimen No.1 should be kept separate, at least for the time being.

\section{Order: Cordaitales}

The genus Cordaites Unger belongs to the order Cordaitales, class Cordaitopsida.

This gymnospermous group had a great palaeoecological and evolutionary importance during the Carboniferous and Permian. Cordaites lived in different habitats - both in moisture conditions of peat-forming swamps and in the community of xerophilous upland flora. They have common ancestors with conifers (see, Šimůnek, 2000). Determination of species of the genus Cordaites is always difficult without knowledge of cuticles; as was documented by Šimůnek (2007), the venation alone is not 


\section{Mona H. Darwish and Yasser A. El Safori}

sufficient for species determination. The preserved venation is a result of taphonomy and mode of preservation of Cordaites leaves before burial.

Specimen No. 10. Cordaites sp. (Plate 2, fig. 5)

Description: Specimen No.10 is a leaf of Cordaites sp. Cordaites are so long that they are rarely found complete. Length more than $12.5 \mathrm{~cm}$, numerous, closely spaced veins run along its length; none of which are more prominent than others (no midvein). The venation pattern depends on whether the adaxial or abaxial side is viewed, and on preservation.

Comparisons: The venation pattern depends on whether the adaxial or abaxial side is viewed, and on preservation (Šimůneket et al. 2009), therefore, it is difficult to identify type of Cordaites with the venation alone.

\section{Genus Artisia Sternberg, 1838}

Artisia is the name (= form-genus) given to pith casts of cordaitalean stems. The pith is a central region of the stem consisting of tissue that easily decays forming a hollow that may be filled by sediment. This central pith cavity is crossed by bands of more decay-resistant tissue that persists giving Artisia its horizontal bands. The Sam Noble Museum: contact@snomnh.ou.edu

Specimen No. 9. Pith cast of Artisia approximate Brongniart ex Lindley \& Hutton, 1837 (Plate 3, fig. 1).

Description: Specimen No.9 illustrates the relatively poor preservation of cast. Cast more or less part of cylindrical, $12 \mathrm{~mm}$ to more in diameter and $50 \mathrm{~mm}$ to more long, bearing alternate approximately horizontal septa and spaces between the septa. The spaces are usually rounded, 0.6 to $2.0 \mathrm{~mm}$ in height.

Comparisons: This specimen is similar to A. Approximate recorded by Šimůnek et al. (2009) from the Radnice Basin (Czech Republic) from the middle Westphalian and differs from $A$. transversa in not having longitudinal ridges.

Specimen No. 7. Pith cast of ? Artisia transversa (Artis) Cordain Sternberg, 1838 (Plate 3, fig. 2).

Description: Specimen No.7 is not complete, transverse and longitudinal ridges septations, may be pith of cordaitalean stems, ? Artisia transversa (Artis) Corda in Sternberg, 1838.

Comparisons: The decorticated stems of Cordaites have been often described under the generic name of Artisia. Itlooks like to those figured by Dilcher et al. (2005) and Šimuneket al (2009) but the Artisia approximata -type does not have the longitudinal ridges as in Artisia transversa.

Specimen No. 11. Unidentified plant roots (Plate 3, fig. $3)$.

Description: Specimen No.11 illustrates the relatively poor preservation of unidentified fossil roots in Quarried block of sandstone.
Specimen No. 12.? Woody trunks (Plate 3, fig. 5 \& 6). Small pieces of petrified woods postponed to further study hoping find letter specimens.

\section{Discussion:}

Carboniferous rocks of Egypt are not characterized by extensive plantation as is well known from many occurrences in the world where plenty of fossil plants and even coal seams are contained within sediments. Many localities from North Africa are similarly rare in their carboniferous records.

The Late Carboniferous flora recorded here from Rod ElHamal Formation is represented by Lycophyta, Sphenophyta, Pterophyta and Cordaitophyta similar to that recorded by Lejal-Nicol (1990) from the uppermost Carboniferous flora (Pteriophyta and Gymnosperms) from Wadi Qaseib which lies $30 \mathrm{Km}$ to the north of Wadi Araba.

Fossil plant remains are contained in the lower Shale unit and at the basal part of the Sandstone unit. They are mostly extracted from the sandstone fluvial flood sediments that intercalated the claystone of the Shale unit. This condition is a good indication that the plant remains were grown up in lagoon and river banks. Intermittently, flood water swashed them and fossilized them within its sandstone deposits (plate 4, Fig. 2 a \& b).

Lepidodendrales species indicate that the climate was very wet and swamp forests were more developed. The characters of, sphenophytes, pteridosperms and cordites indicate that the climate was not as hot as the Lower Carboniferous. However, this condition enhances seasonal fluvial floods that swashed the swampy wetlands and preserved floral fragments within sandstones of flood channels.

Flora types present similarities to the Late Carboniferous flora of Africa; Alabama; Slovenia; Canada and Bulgaria (Lejal-Nicol 1990; Dilcheret al. 2005; KolarJurkovšekand Jurkovšek 2007 \& 2012; lvarez-V. zquezand Wagner 2014; Thomas et al. 2010 and Tenchov $\&$ Thomas 2015). The progress of coarse sedimentation and the presence of marine fauna at the upper units of the studied section reveal a major period of Late Carboniferous warming up. Further collection from the present locality is required because Late Carboniferous in Egypt is not well documented.

\section{Acknowledgments}

Thanks are due to Dr. Wagieh El- Saadawi, Professor of Botany, Faculty of Science, Ain Shams University, whose valuable remarks were of great help. Special thanks to Prof. Dr. Marouf A. Abd El hameed (Geology Department, Faculty of Science, Ain Shams University) for collecting the plant fossils specimens. Thanks to Mr. Mohamed Farag (Botany Department, Faculty of Science, Ain Shams University) for his kind help with the digital plate. 


\section{Late Carboniferous Macroflora from Rod El-Hamal Formation Wadi Araba}

\section{References}

Abdallah, A. M. and EL Adindani, A. 1965: Stratigraphy of Upper Paleozoic rocks, western side of the Gulf of Suez. - Geol. Surv. Cairo, Egypt. 25: 1-18.

Abdel-Shafy, E., Abdallah A. and Abdel-Azeam, S. 2000: Palaeontology andPalaeoecology of the Upper Palaeozoic transitional strata in the western side of the Gulf of Suez, Egypt. In: Proceeding $2^{\text {nd }}$ Symposium Geology of Pre-Cretaceous and development in Egypt.pp. 121-146.

Álvarez-Vázquez, C. and Wagner, H. 2014: Lycopsida from the lower Westphalian (Middle Pennsylvanian) of the Maritime Provinces, Canada. Atlantic Geology. 50, $167-232$.

Anderson, J. M., Anderson, H. M. and Cleal. C. J. 2007: Brief history of the gymnosperms: classification, biodiversity, phytogeography and ecology. Strelitzia.20:1-279.

Ball, J. 1916: The geography and geology of west-central Sinai. - Egypt. Surv. Dept., p. 151-163, Cairo.

Barakat, M. G., Darwish, M.and El barkooky, A. N. 1984: On the occurrence of Ferruginous plant remains in the Upper Carboniferous Sandstones, Sinai, Egypt. NIDOC, Dokki, Cairo, Egypt.

Boureau, E. 1954: Sur la presence d'uneflore carbonifèredans l'Air (Sahara central). Bull.Soc.Geol.Fr. 6 (3): 293-298.

Boureau, E.1958: Paléobotanique africaine. Bull. Sci. C.T.H.S., 2, p. 7, pl. 2 Cuvillier J. 1928. Les végétaux fossilesd'Egypte. Bull. Soc. Geograph. Egypte. 15: 289305.

Brongniart, A. 1828. Prodromed'une histoire des v.g.tauxfossiles. Dictionaire des sciences naturelles. 57, $1-223$.

Corsin, P. 1960: Classification des Ptéridophyteset des Ptéridospermophytes du Carbonifère. Bulletin de la Sociétégéologique de France (7e série). 2: 566-572.

Cózar, P. Somerville I, Vachard, D. , Coronado, I., García-Frank, A., Medina-Varea, P., Said, I., Del Moral, B. and Rodríguez, S. 2015: Upper Mississippian to lower Pennsylvanian biostratigraphic correlation of the Sahara Platform successions on the northern margin of Gondwana (Morocco, Algeria, Libya)-Gondwana Research, in press.

Cuvillier, J. 1928: Les végétaux fossils d’Egypte. Bull. Soc.Geograph. Egypte. 15:289-305.

Darwish, M. H. 1990: Studies on some Egyptian fossil plants. Ph. D. Thesis. Dept. Bot. Fac. of Girls, Ain Shams Univ. Cairo.

Darwish, M. H. \& El-Kelani, A. 2001: Lower Carboniferous plants from Abou-Thora Formation in Southwest Sinai. Taeckholmia. 21(1): 27-34.

Darwish, M. H. and Awad, S. A. 2002: Plant Fragments from Tufa Deposits (Quaternary), Kharga Oasis, Egypt. Pakistan Journal of Biological Sciences. 5 (11): 2002.

Dilcher, D. L., Tott, T. A. \& Axsmith B. J. 2005: fossil plants from the Union Chapel Mine, Alabama. Alabama Paleontological Society Monograph. no. 1, p. 153-168.

El Safori, Y. 2015: Late Carboniferous bryozoans from Wadi Araba. $15^{\text {th }}$ Conference of the Egyptian society of paleontology, Cairo, (Abstract).
El-Shazly, S. 2011: Late Carboniferous macrofauna from Wadi Araba, Eastern Desert, Egypt, and their paleoecological implications Journal of African Earth Sciences. 61. 369-394.

Grier, N. M. 1917: New Forms of Calamites. The American Midland Naturalist, Vol. 5, No. 6, pp. 147-150. Grierson, J. D. and Banks, H.P.1963: Lycopods of the Devonian of New York State.Palaeontogr.Am.4:221-295. Hartung W. 1938: Flora und Altersstellung des Karbons von Hainichen-Ebersdorf und Bornabei Chemnitz. Abhandlungendes

SächsischenGeologischenLandesamts18:1-140.

Hirmer, M. 1927: Handbuch der Paläobotanik. Band I: Thallophyta-Bryophyta-Pteridophyta. Verlag R. Oldenbourg, Munchen und Berlin. 708 p.

Horowitz, A. 1973: Noeggerathiadickeri from the carboniferous of Sinai. Rev. Palaeobot. Palynol. (15)1: 5156.

http://www.redbor.pl/skamienialosci/0_atlas_flory_ka rbonu.htm.

Hübers M., Bomfleur B., Krings M., Pott C. \& Kerp H. 2014: A reappraisal of Mississippian (Tournaisian and Visean) adpression floras from central and northwestern Europe. Zitteliana. A 54, 39.

Issawi,B. and Jux, U. 1982: Contrributions to the stratigraphy of the Paleozoic rocks in Egypt. Geol. Surv. Egypt. Paper 64, pp. 28.

Jongmans, W. J. \& Koopmans, S. 1940: Contribution to the Flora of The Carboniferous of Egypt. Meded. Geol. Bureau Heerlen. 223-229.

Jongmans, W. J. \& Van der Heide S.,1955: Flore etFaune du Carbonféreinférieur de L'Égypte. Medded V.Geol. Sticht. n.s. 8:59-76.

Klitzsch, E. \&Lejal-Nicol, A. 1984: Flora and fauna from strata in southern Egypt and northern Sudan (Nubia and surrounding areas). Berliner geowiss. Abh., (A) 50, p. 47 79.

Klitzsch, E. 1990. Palaeozoic. In: Said, R. (Ed.), The Geology of Egypt. A.A. Balkama, Rottredam . pp. 393406.

Kolar-Jurkovšek, T. and Jurkovšek, B. 2007: Zgornjekarbonska flora Grajskegahriba v Ljubljani [Late Carboniferous flora of Castle Hill in Ljubljana (Slovenia) - in Slovenian - Geologija, 50(1): 9-18.

kolar-Jurkovšek, T. and Jurkovšek, B. 2012: Late Carboniferous floras of Slovenia - a review. Geologia Croatica, 65(3):323-328.

Kora, M. 1995: Carboniferous macrofauna from Sinai, Egypt: biostratigraphy and paleogeography. Journal of African Earth Science.20 (1):37-51.

Kora, M. and Mansour, Y. 1992: Stratigraphy of some Permo-Carboniferous successions in Northern Galala, Gulf of Suez region, Egypt. Jahrbuch der Geologischen Paläont. Abh. Stuttgart. 185(3): 377-394.

Kräusel, R . 1939. Ergebnisse der Forschungsreisen Prof. E. Stromers in den Wüsten Ägyptens. 111 Die fossilens Floren Ägyptens. Abh. Bay. Akad. Wiss. Math. Nat.Abt. München. 47:1-140.

Kräusel, R. and Stromer, E. 1924. Ergebnisse der Forschungsreisen Prof. E. Stromers in den WüstenÄgyptens. 1V. Die fossilens Floren Ägyptens, 3. 


\section{Mona H. Darwish and Yasser A. El Safori}

Die fossilens Pflanzen Ägyptens, A-C. Abh. Bay.Akad. Wiss. München (N.F.) 30(2): 1-48, pls.1-3.

Lejal-Nicol, A. 1987. Flores nouvelles du Paleozoiqueet du Mesozoique de L'Egypte et du Soudan septentrional. Berliner Geowiss.Abh. 75(A): 151-248.

Lejal-Nicol, A. 1990. Fossil flora, Ch. 29 In (ed. R. Said): The Geology of Egypt. 615-625. Balkema. Rotterdam, Brookfield.

Lejal-Nicol, A. and Boureau, E. 1981: A propos de nouvelles flores plaeozoiques et mesozoique de L'Egypte du sud-ouest. C. R. Acad. Sci. 292(11): 1337-1340.

Lesquereux, L., 1879-1884: Description of the coal flora of the Carboniferous Formation in Pennsylvania and throughout the United States: Second Pennsylvania Geological Survey, 3 vols. Atlas (1879), p. 1-18, 85 pls; v. 1-2 (1880), p. 1-694. v. 3 (1884), p. 695-975.

Lindley, J. and Hutton, W. 1833: The fossil flora of Great Britain. Volume 2. James Ridgeway, London.xxviii +208 p.

Meyen, S. V. 1976: Carboniferous and Pemian Lepidophytes of Angaralaud, Palaeontographica. 1578: 772-757.

Němejc, F. 1947: The Lepidodendraceae of the coaldistricts of Central Bohemia. SborníkNárodního Musea.7, B, 2: 45-87.

Newton, R. B. 1909: On some fossils from the Nubian Sandstone Series of Egypt. Geol. Mag., London, dec. V, 6: 352-359.

Omara, S. and Kenawy, A., 1966: Upper Carboniferous microfossils from Wadi Araba, Eastern Desert, Egypt. Jahrbuch der Geologischen Palaeont. Abh. Stuttgart. 124(1): 56-83.

Pšenička J., Opluštil S., Ronchi A. \& Šimůnek Z. 2012: Revision of the Pennsylvanian flora from Val Sanagra in Westerv Part of the Southern Alps (Italy). Folia vol. 46, No. 1-2.

Said, R., 1962: The geology of Egypt. Elsevier Publishing Co., Amsterdam, New York, 377 p.

Salter, J. W. 1868: On a true coal-plant Lepidodendron from Sinai. Quart. J. Géol. Soc., London, 24: 509-510.

Schürmann, H. M. E., Burger, D. and Dijkstra, J. 1963: Permian near Wadi Araba, Eastern Desert, Egypt. Geol. Nmijnbouw 42: 329-336.

Seward, A.C. 1907: Fossil plants from Egypt. Geol. Magaz., Des. 5, Vol. 4:253-257, 3 Textfig. London.

Seward, A.C. 1910: Fossil plants. A textbook for students of botany and geology. Volume 2. Cambridge University Press, Cambridge. 622 p.

Seward, A. C. 1932: Carboniferous plants from Sinai.Q.J.Geol.Soc. 88: 350-357.

Šmůnek, Z. 2000: Cuticles of Cordaites from the Westphalian, Stephanian and Autunian of the Bohemian Massif (Czech Republic) a preliminary study). ActaPalaeobot. 40(1): 25-34.

Śimůnek, Z. 2007: New Classification of the genus Cordaites from the Carboniferous and Permian of the Bohemian Massif, based on cuticle micromorphology. SborníkNárodníhomuzea v Praze, řada B-přírodnívědy ActaMuseiNationalis Prague, Ser. B. Historia Naturalis.
62, 3-4, 97-210.

Simůnek, Z., Opluštil, S. and Drábková, J. 2009.Cordaites borassifolius (Sternberg) Unger (Cordaitales) from the Radnice Basin (Bolsovian, Czech Republic). Bulletin of Geosciences. 84(2): 301-336 (33 figures, 3 tables).

Sternberg, K. von 1820-1838: Versuch einergeognostisch botanischer Darstellung der Flora der Vorwelt. I (1820-1825) 1 (1820): 1-24, Tafn I-XIII; 2 (1823): 1-33, Tafn XIV-XXVI; 3(1824): 1-40, Tafn XXVII-XXXIX; 4(1825): 1-48, Tafn XL-LIX, Tafn AE. II (1833-1838) - 5/6 (1833): 1-80, Tafn I-XXVI; 7/8 (1838): 81-220, Tafn I-LXVIII, Tafn A, B (incl. Corda: Skizzen zurvergleichenden Phytotomievor- und jetztweltlicher Pflanzenst.mme, I-LXXI).

Suckow, G. A. 1784: Beschreibung einigermerkwürdigen Abdrücke von der Art der sogenannten Calamiten. Hist, Comm, Acad, elect. Sci. litt. Theod - Palat. vol. v. p. 355. Mannheim.

Taylor, T. N. and Taylor E. L. and Krings M. 2009: Paleobotany: The Biology and Evolution of Fossil Plants. Academic Press .1230 p.

Tenchov, Y. G. and Thomas, B. A. 2015. Lycophyte distribution in the Pennsylvannian of the Dobrudzha coalfield, Bulgaria and their value in climatic interpretation. Acta Palaeontologica Romaniae.V. 11(2): 3-8

Thomas B. A. and Meyen S. V. 1984: A system of formgenera for the upper palaeozoiclepidophyte stems represented by compression-impression material. Review of Palaeobotany and Palynology.Vol. 41, Issues 3-4: 273281.

Thomas B. A., Zodrow E. and Cleal C. J. 2010. Leafy branches of Bothrodendronpunctatum from the Westphalian D (Asturian) of Nova Scotia, Canada Atlantic Geology. 46: 1-6.

Tidwell, W.D., Jennings, J.R. and Call V.B. 1988: Flora of Manning Canyon Shale, Part III: Sphenophyta. Brigham Young University.Geological Studies.Vol.35.

Unger, F. 1850: Genera et species plantarum fossilium. 627 pp. Wilhelm Braunmuller, Wien.

Villalba-Breva, S. and Martín-Closas, C. 2009: Plant Taphonomy from the MississippianFlyschFacies of the El Priorat Massif (Catalonia, Spain). Journal of Taphonomy.7 (3-4):249-262.

Wagner, R. H. and Álvarez-Vázquez, C. 2010: A redescription of the Stephanian species Callipteridium virginianum (Fontaine \& White, 1880) comb. nov. and Alethopteris leonensis Wagner, 1964. Scripta Geol., Spec. Issue 7.

Walther, J. 1980: Übereine Kohlenkalk-Fauna ausder ägyptisch-arabischen Wüste. Z. dt. geol. Ges. 42: 419449; Berlin.

Weiss, Ch. E. 1870: Studienuber Odontopteriden. Zeitschrift der DeutschengeologischenGesellschaft, Berlin. 22: 853-888.

Yousef, S. G. 1993: Studies on some Egyptian fossil woods. Ph. D. Thesis, Bot. Dept., Fac. of Sci., Zagazig Univ. Benha 


\section{Mona H. Darwish and Yasser A. El Safori}

\section{Plate 1}

Figure.1. Specimen No. 4. Lepidodendron veltheimii Sternberg 1825. A portion of a stem. Leaf cushions continuous with other cushions above and below generally contiguous but separated from each other by little distance. Arrow shows one leaf cushion with leaf scar. Scale bar $=1 \mathrm{~cm}$.

Figure.2. Specimen No. 6. Lepidodendron lycopodioides Sternberg 1823. A portion of a stem. Fusiform, to longitudinally rhomboid leaf cushions with leaf scar(arrow), intervals irregularly striate lengthwise. Scale bar $=1 \mathrm{~cm}$.

Figure.3. Specimen No. 2. Lepidodendron rimosum, Sternberg 1820. A portion of a stem. Rhomboidal, elongated, convex, carinate, leaf cushions with prominent small, rhomboidal leaf scar, different wide separation between leaf cushions appears. Arrows: (a) shows one leaf cushion \& (b) leaf scar. Scale bar $=1 \mathrm{~cm}$.
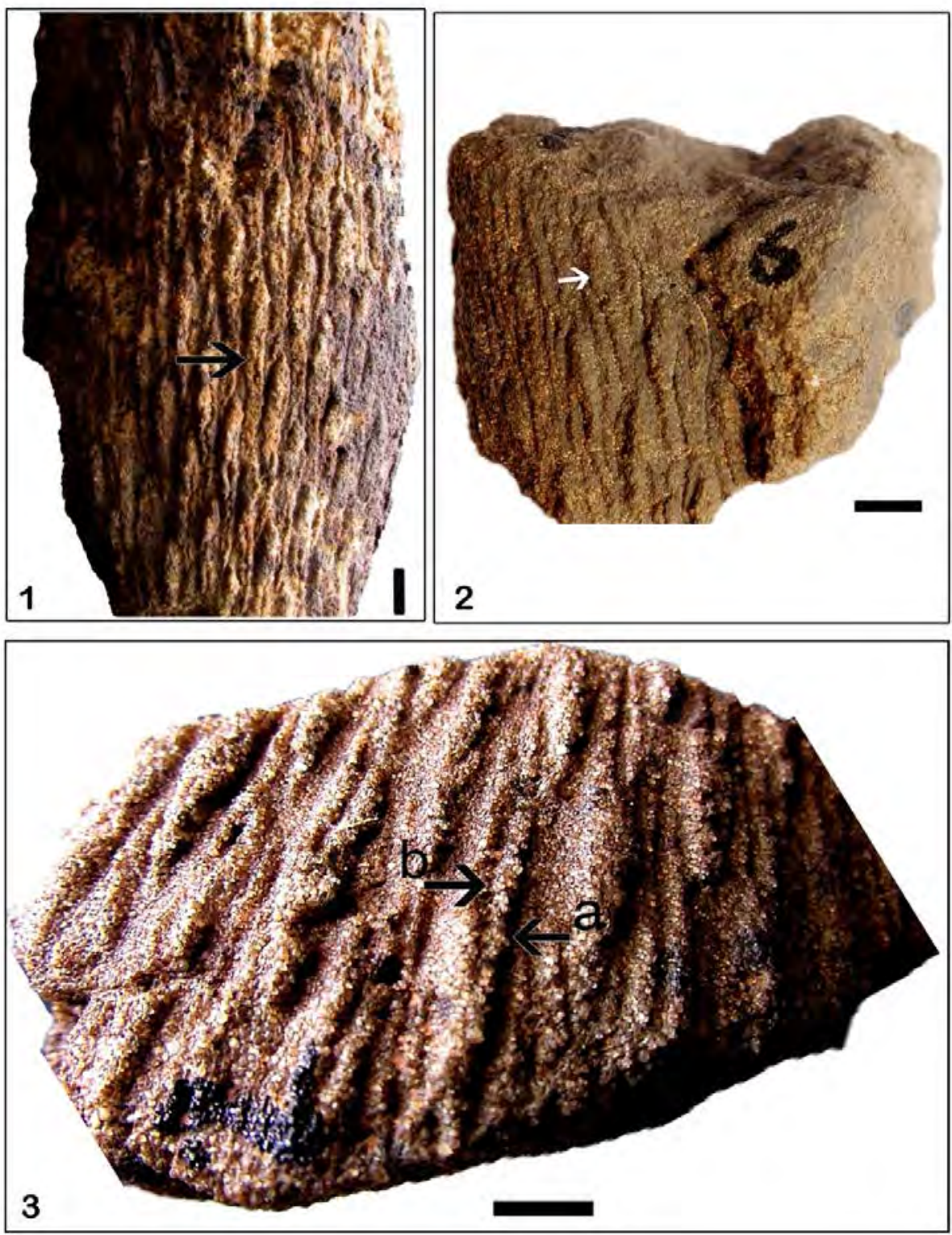


\section{Late Carboniferous Macroflora from Rod El-Hamal Formation Wadi Araba}

\section{Plate 2}

Figure.1. Specimen No. 8. Calamites (Crucicalamites) cruciatus Sternberg 1825. Fragment showing nodes \& internodes with clearly marked nodal lines (arrow a) and branch scars (arrows b \& c). Scale bar $=1 \mathrm{~cm}$.

Figure.2. Specimen No. 3. Calamite (Mesocalamites) roemeri Goeppert, 1850. A fragment of a stem shows the internode bundles may be alternate or passing straight through the node. Scale bar $=1 \mathrm{~cm}$.

Figure.3. Specimen No. 1. Callipteridium sp. A part of pinna shows pinnules, parallel-sided. Midrib light marked, straight, extending to near the pinnule apex; lateral veins perpendicular to both the midrib and the pinnule margin usually once to twice forked near margin (arrow). Scale bar $=1 \mathrm{~cm}$.

Figure.4. Specimen No. 1. Callipteridium sp. A part of pinna shows pinnules, parallel-sided with narrow furrows (arrow: a) bases lack the narrow confluence between pinnules. Midrib light marked, straight, extending to near the pinnule apex (arrow: b). Scale bar $=1 \mathrm{~cm}$.

Figure.5. Specimen No. 10. Cordaites sp. Part of a leaf, numerous, closely spaced veins run along its length; none of which are more prominent than others (no mid vein). Scale bar $=1 \mathrm{~cm}$.
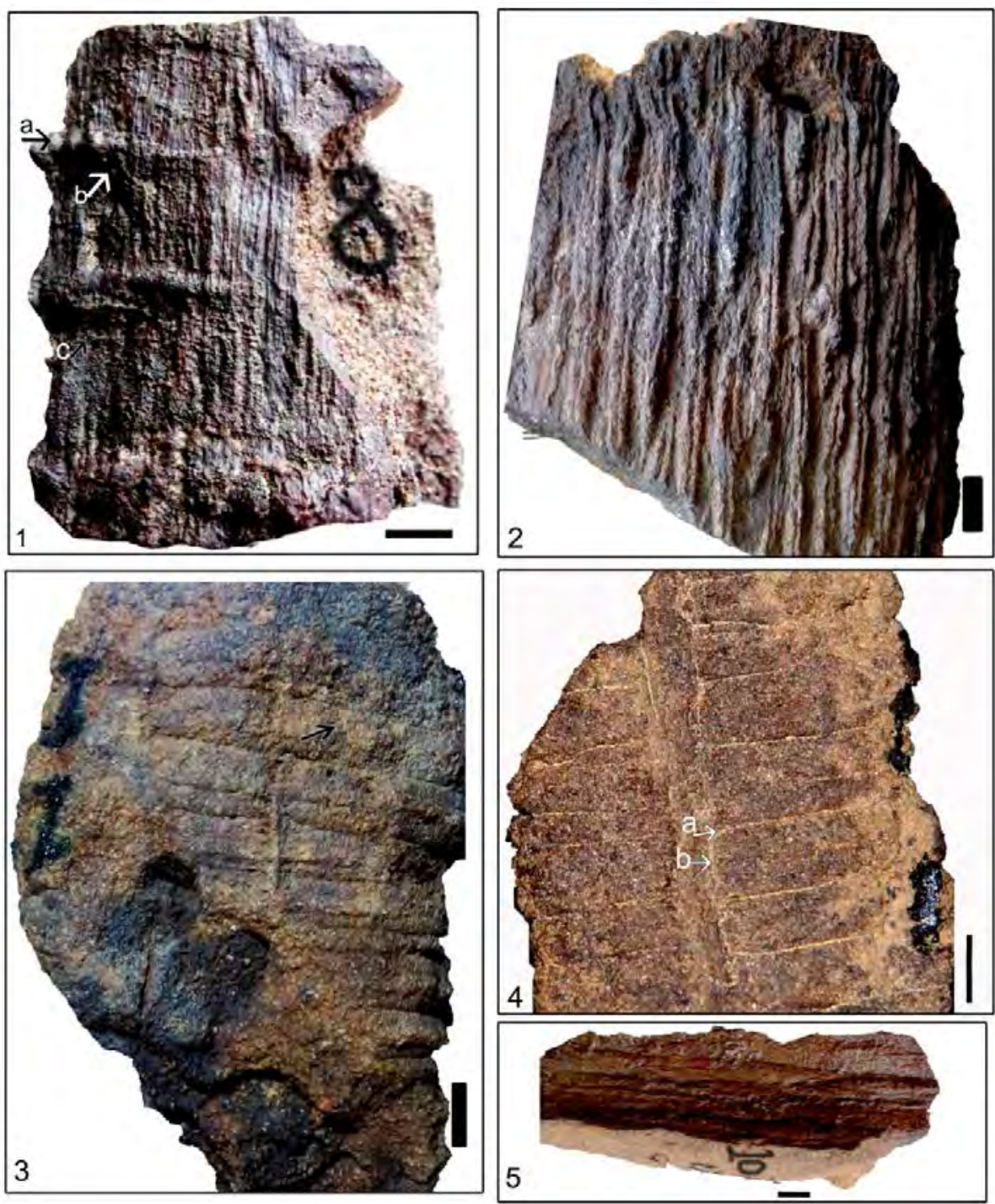


\section{Mona H. Darwish and Yasser A. El Safori}

\section{Plate 3}

Figure.1. Specimen No. 9. ? Artisia approximate.A cast of pith is bearing alternate approximately horizontal septa and spaces between the septa. Scale bar $=1 \mathrm{~cm}$.

Figure.2. Specimen No. 7. ? Artisia transversa. A cast of pith showslongitudinal (arrow:a) and transverse (arrow: b) ridges septations. Scale bar $=1 \mathrm{~cm}$.

Figure.3. Specimen No. 11. preservation of unidentified fossil branched roots(arrows). Scale bar $=1 \mathrm{~cm}$. Figures. 4 \& 5. Specimen No. 12. Small woody trunks Scale bar $=1 \mathrm{~cm}$.

Figure.4. Specimen No. 13. Bothrodendron cf. punctatum Lindley and Hutton 1833. A portion of a stem shows number of minute dots, arranged in a quincuncial manner and a cavity. Scale bar $=1 \mathrm{~cm}$.
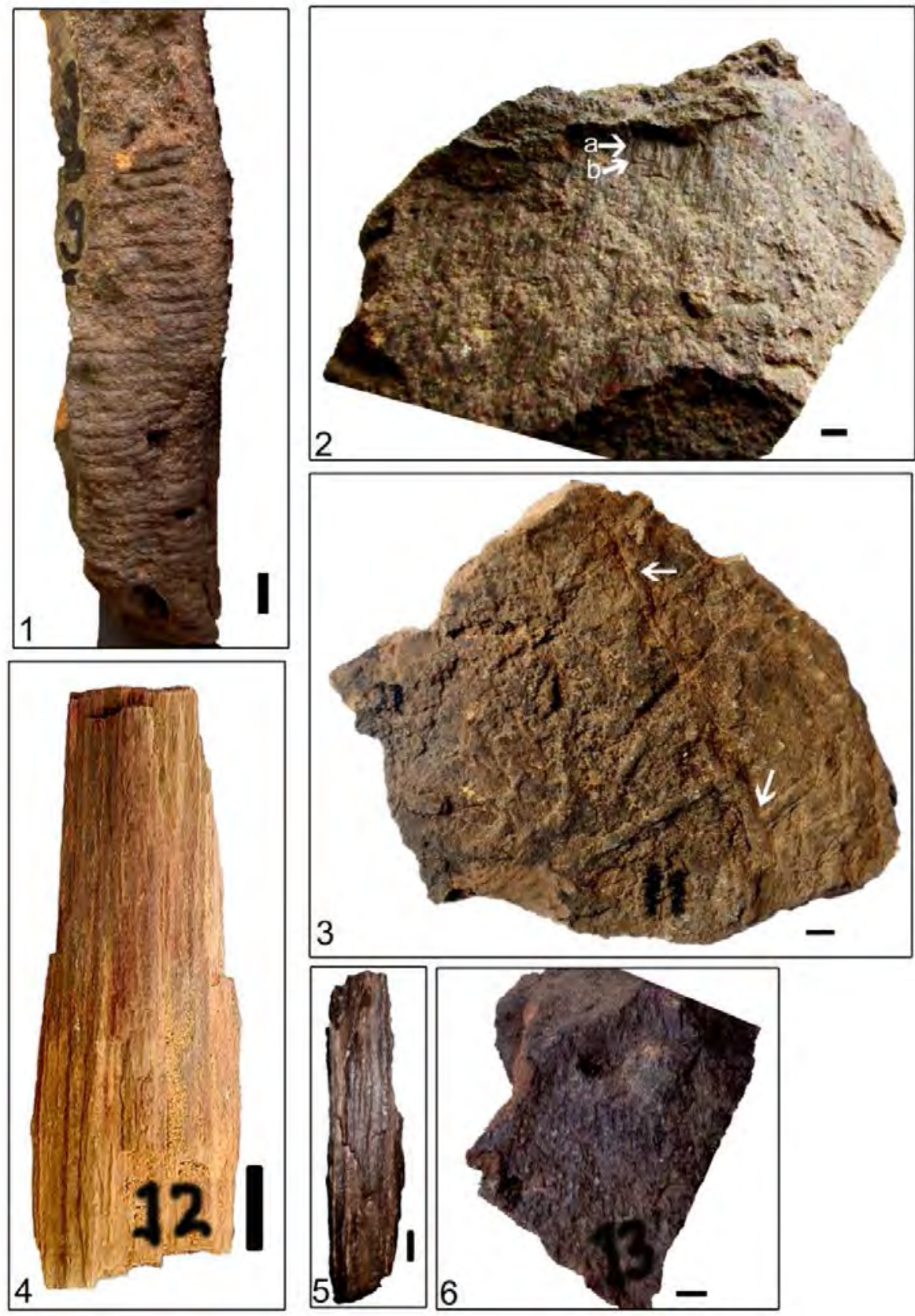


\section{Late Carboniferous Macroflora from Rod El-Hamal Formation Wadi Araba}

\section{Plate 4}

Figure 1. The field photograph showing the lower part of the studied section with swamp claystone (Clst) with intermittent minor and major fluvial sandstones (S.S.).

Figure 2. a: A diagram showing the lagoonal flora, and river banks flora. 2. b, the same section immediately after a major flooding.

Figure 3. The field photograph of a fragment of fossil plant in a fallen rock block of the sandstones interbeds, Wadi Araba, Rod El-Hamal Formation, Shale unit.

Figure 4. A stem fragment of fossil plant in the sandstones interbeds, Wadi Araba, Rod El-Hamal Formation, Shale unit.
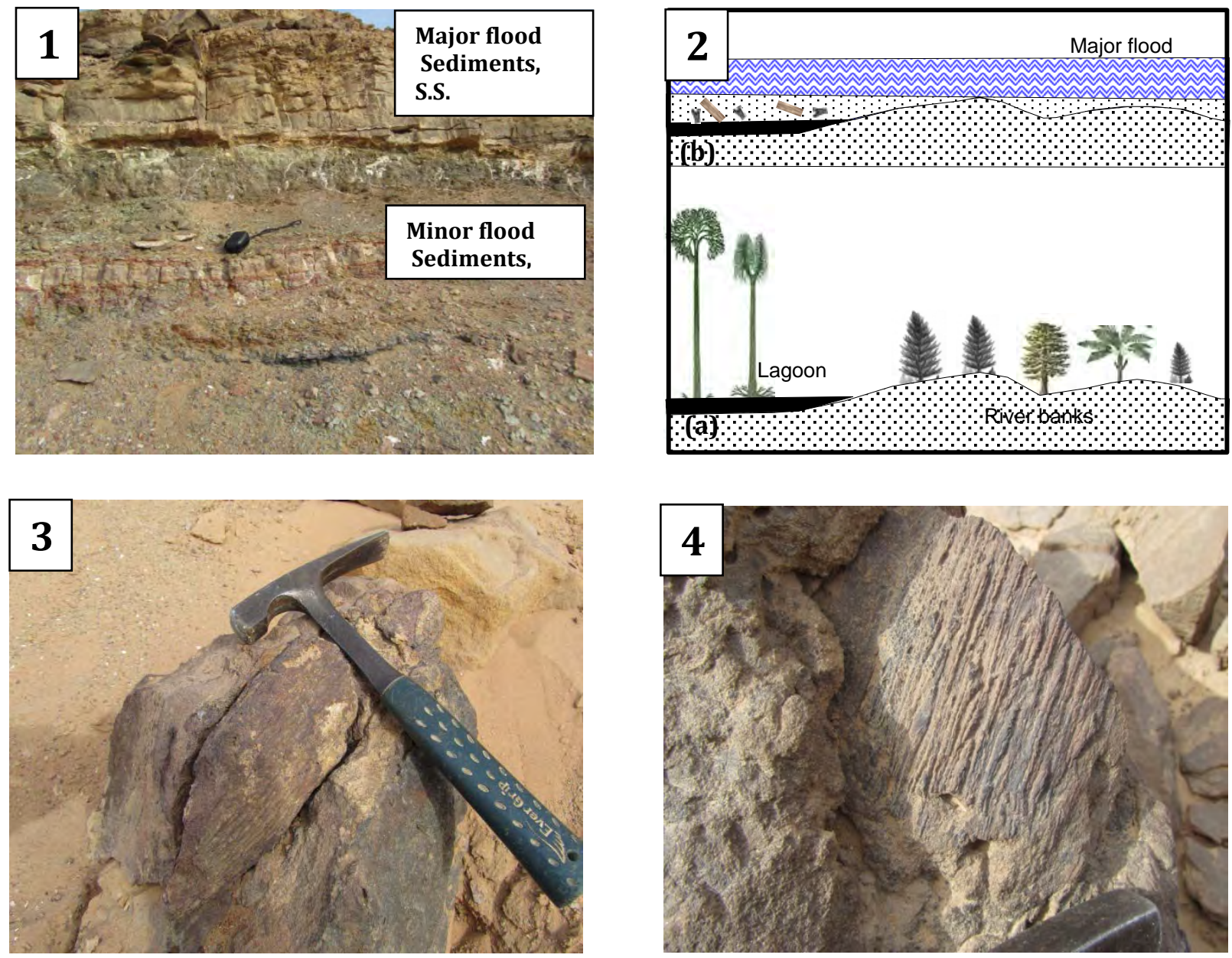